Revista Brasileira de Agricultura Irrigada v.8, nº. 2, p. 161 - 170, 2014

ISSN 1982-7679 (On-line)

Fortaleza, CE, INOVAGRI - http://www.inovagri.org.br

DOI: $10.7127 /$ rbai.v8n200223

Protocolo 223/14 - 30/11/2013 Aprovado em 17/03/2014

\title{
USE OF TDR SENSOR LAPTOP IN THE DISTRIBUTION OF WATER CONTENT IN NO-TILLAGE
}

Claudinei Martins Guimarães ${ }^{1}$, Oleico Garcia Ciriaco ${ }^{2}$, Carlos Alexandre Gomes Costa ${ }^{3}$, João Batista Leite Junior ${ }^{3}$, Lázaro Henrique Luca Costa² ${ }^{2}$ Lazaro Vinicius Moraes Lima².

\begin{abstract}
Researches related to understanding the distribution of soil moisture in non-tillage system, seek to asset the degree of homogeneity of water availability to plant soft his management system. Therefore, the aim of this study was to evaluate the spatial distribution of soil moisture in non-tillage system in an Oxisol in the south western region of Goiás using a TDR sensor. This was done using the TDR (Time Domain Reflectometry) sensor, from Campbell Scientific Company, the Hidrosense model with stems of 0.12 meters length. The work was carried out during the initial planting of 2013/14 season, in november 2013, on the three most superficial layers $(0-0.12,0.12-0.24$ and $0.24-0.36$ meters $)$. The precipitation before moisture data collection was not enough to moisten the entire soil profile analyzed. Therefore, values of soil moisture between 18 and 56\% were observed. Some related researches done near the area addressed in this research area indicate that the maximum moisture near the saturation condition is $52 \%$ of moisture on a volumetric basis. However, it was observed a variation of approximately $10 \%$ between the measured values in the field and on the water retention curve of the soil. Therefore, this preliminary analysis of the distribution of soil moisture, provide elements for refined calibration of this instrument enabling a larger sample moisture data measured directly in the field without the need to collect soil samples and subsequent laboratory analysis.
\end{abstract}

Keywords: oxisol, time domain reflectometry, soil moisture, relative difference.

\section{USO DE SENSOR TDR PORTÁTIL NA DISTRIBUIÇÃO DO CONTEÚDO DE ÁGUA EM PLANTIO DIRETO}

\section{RESUMO}

\footnotetext{
${ }^{1}$ Mestrando do Programa de Pós-Graduação em Agronomia/ Produção Vegetal, Universidade Federal de Goiás (UFG), Campus Jataí, BR 364, km 193, no 3800, CEP 75801-615, Jataí, GO. Fone (64) 8402-4449. E-mail neiufv@gmail.com

${ }^{2}$ Aluno de graduação do curso de agronomia, UFG-Campus Jataí, GO. oleicogs@ gmail.com; lazarolucac@gmail.com; lazarovinicius85@hotmail.com

${ }^{3}$ Prof. Doutor, UFG, Campus Jataí, GO. alexandre costa@ufg.br; joaoleitejr@ibest.com.br
} 
Pesquisas relacionadas a entendimento da distribuição da umidade do solo no sistema de Plantio Direto (PD) buscam avaliar a grau de homogeneidade da disponibilidade hídrica para as plantas deste sistema de manejo. Portanto, objetivou-se com este trabalho avaliar a distribuição espacial da umidade do solo em sistema de Plantio Direto em Latossolo Vermelho distroférrico na região sudoeste de Goiás com o uso de um sensor tipo TDR. Para isso, utilizou - se o sensor TDR (Time Domain Reflectometry) da empresa Campbell Scientific, modelo Hidrosense com hastes de $0,12 \mathrm{~m}$ de comprimento. O trabalho foi conduzido durante o início do plantio da safra 2013/14, mês de novembro de 2013, nas três camadas mais superficiais $(0-0,12 \mathrm{~m} ; 0,12-0,24 \mathrm{~m} ; 0,24-0,36 \mathrm{~m})$. A precipitação antecedente à coleta de dados não foi suficiente para umedecer todo o perfil de solo analisado. Por isso, foram observados valores de umidade do solo entre 18 e $56 \%$. Alguns trabalhos realizados em área próxima a área abordada nesta pesquisa indicam que a máxima umidade na condição próxima à saturação é de $52 \%$ de umidade na base volumétrica. Observa-se, portanto, uma variação de aproximadamente $10 \%$ entre os valores medidos no campo e o relativo à curva de retenção da água no solo. Portanto, esta análise preliminar da distribuição da umidade do solo subsidiará elementos para uma calibração refinada deste instrumento viabilizando uma maior amostragem de dados de umidade medidas diretamente no campo sem a necessidade de coleta de amostras de solo e posterior análise laboratorial.

Palavras-chave: latossolo, time domain reflectometry, umidade do solo, diferença relativa.

\section{INTRODUCTION}

Water is the main factor that determines the productivity of a culture, as in the plant, it participates in the main metabolic reactions, from growth to reproduction, and the soil is responsible for the handling, solubilization and absorption of nutrients by the roots. The lack of water or its excess decisively affects plant development.

Through all its development, the plant absorbs and loses water, so the soil becomes a reservoir of water and nutrients. The amount of water consumed by a crop during its development varies with the spatial and temporal distribution of climate, variety of culture and management of the agricultural system, which alters the physical properties of the soil directly related to the storage of water (Moreti et al., 2007). Thus, it is observed that the system of cultivation is one of the main parameters inherent in the dynamics of soil water, therefore, several studies indicate that no-tillage system, soil quality is maintained and/or improved by even greater contribution organic matter due to the straw kept at the ground surface.

It is noteworthy that due to the large spatial variability of physical and hydraulic properties is necessary to use a method in establishing points which best represent an area. Temporal stability enables the identification of points in the field that reflect the average behavior of a variable, ie, the points that have similar average values. Identifying them is crucial in planning monitoring programs hydrological variables, it 
allows the reduction related to the measurement costs of field data (Avila et al., 2010).

Near-surface soil moisture is a key variable for the description of many hydrological and climatic processes. In particular, the distribution of themass and energy fluxes between the soil and the first layer of the atmosphere is controlled by soil moisture which is characterized by a high spatio-temporal variability also at small spatial scale (Bell et al., 1980; Francis et al.,1986;Munoz-Pardo et al.,1990; Fitzjohn et al.,1998;Seyfried,1998; Hupet and Vanclooster, 2002; Schume et al., 2003; Hupet and Vanclooster, 2005; Lin et al., 2006; Brocca et al., 2007), citados por Brocca, 2008. New methodologies for the optimization of the number of observations without losing information become more and more important. By using a statistical approach, Brocca et al. (2007) determined, as a function of the wetness conditions, the number of point measurements required to estimate the average of the soil moisture of a specific area located in inland regions and characterized by a Mediterranean climate. The temporal stability concept introduced by Vachaud et al. (1985) may be also used to optimize the sampling scheme. It refers to "the time stability of the rank of individual observations in the probability distribution function of the whole population" (Vachaud et al., 1985) and helps to identify, within an area of interest, the location of points representing accurately the average soil moisture of the overall area. In practice, if the spatial distribution of soil moisture exhibits temporal stability then its estimation over large areas through a limited number of measurements would be possible (Brocca, 2008).

Knowledge of the spatial variation of soil moisture is indispensable to perform analyzes such as temporal stability, since studying the variation both in space and in time. Therefore, the aim of this study was to evaluate the spatial distribution of soil moisture in non-tillage system in an Oxisol during the growing season in the south western region of Goiás using a TDR sensor.

\section{MATERIAL E METHODS}

\section{EXPERIMENT LOCATION}

The experiment was conducted in an experimental area at the Federal University of Goiás - UFG, Jataí Campus, in southwest Goiás state, with $17^{\circ} 52$ '53 "S latitude and $51^{\circ} 42^{\prime}$ '52" W longitude, with $696 \mathrm{~m}$ of altitude located in a region of predominantly $\mathrm{Cw}$ climate, mesothermal, according to the Köppen classification, which is characterized by having a rainy tropical climate, with rains in summer and dry in winter and mean annual precipitation ranging from 1600 to $1700 \mathrm{~mm}$, with a concentration of rainfall during the period from November to May and dry season from June to 
September. The studied soil is classified as Typic Distroferric Oxisol (Embrapa, 1999).

\section{EXPERIMENTAL AREA}

The experimental area is cultivated with soybeans and corn under no-tillage (direct sowing) system since 2009 and has a total area of 1 ha $(100 \times 100 \mathrm{~m})$, divided into a regular grid with 9 cells measuring $33.3 \times 33.3 \mathrm{~m}$ each, where the points were defined for data collection, at the intersection of the cells with the aid of a GPS device (Figure 1).
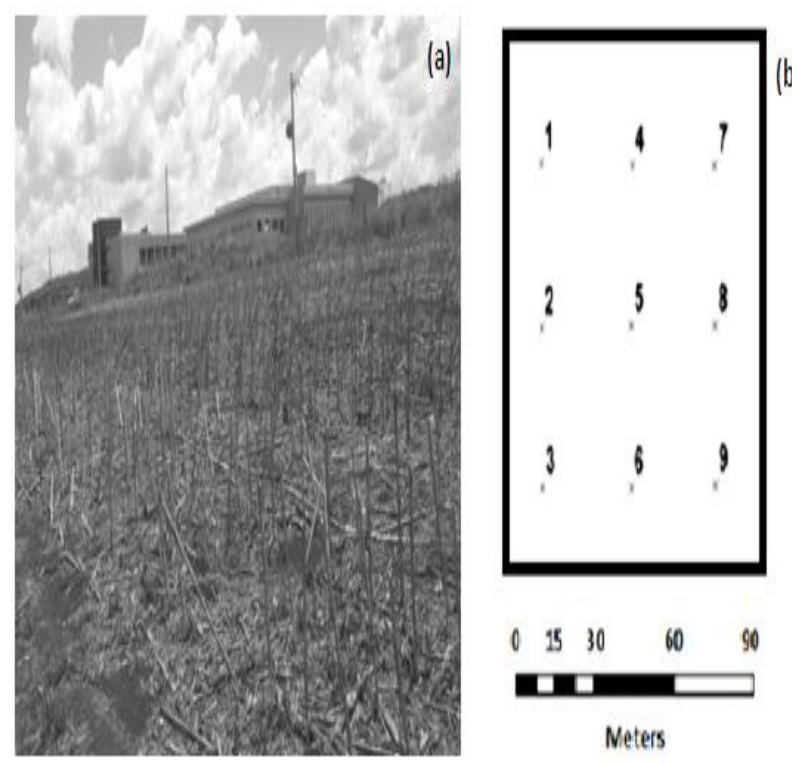

Figure 1. (a) Experimental area used and (b) layout of the distribution of sample points where the data of soil moisture using TDR sensors were collected.

\section{SAMPLING AND DATA COLLECTION}

With predetermined points, data collection of soil water content at depths from 0 to 0.12 , 0.12 to 0.12 to 0.24 and 0.24 to $0.36 \mathrm{~m}$, occurred early in the planting of 2013/2014 season, specifically in the month October 2013 with readings by means of a portable type Time Domain Reflectrometry (TDR), the Hidrosense model, manufactured by Campbell Scientific Company. This equipment provides instant data of water content in soil based on volume, relying on the speed of propagation of electromagnetic pulses between her two stems of 0.12 meters length each, after which inserted vertically into the soil, provide monitoring of a layer $12 \mathrm{~cm}$ depth. Four replicates were collected randomly within a radius of 1 meter away from each point, yielding an arithmetic mean of the later repetitions 4 to represent the observed value in each of these points were made.

According to Vachaud et al. (1985), the mean relative difference can be calculated by the expression:

$$
\bar{\delta}_{\mathrm{ij}}=\frac{\theta_{\mathrm{ij}}-\theta_{\mathrm{j}}}{\bar{\theta}_{\mathrm{j}}}
$$

where $\bar{\delta}_{i j}$ is the average relative difference in position $\mathrm{i}$ at time $\mathrm{j}, \theta \mathrm{ij}$ is the value of water content in soil in the position $\mathrm{i}$ and time $\mathrm{j}$, and $\bar{\theta}_{\mathrm{i}}$ is the average water content in the soil in all positions $\mathrm{j}$ in the time. 


\section{RESULTS AND DISCUSSION}

The precipitation before moisture (Figure 2) data collection was not enough to moisten the entire soil profile analyzed. In table 1, there was a decrease in the values of water content with increasing depth, so at each point, as the overall average, which is an insufficient volume of precipitation to infiltrate throughout the soil profile, since samples were collected at the beginning of the rainy season, when the soil still met with water content well below field capacity, especially the layer from 0.24 to 0.36 m.

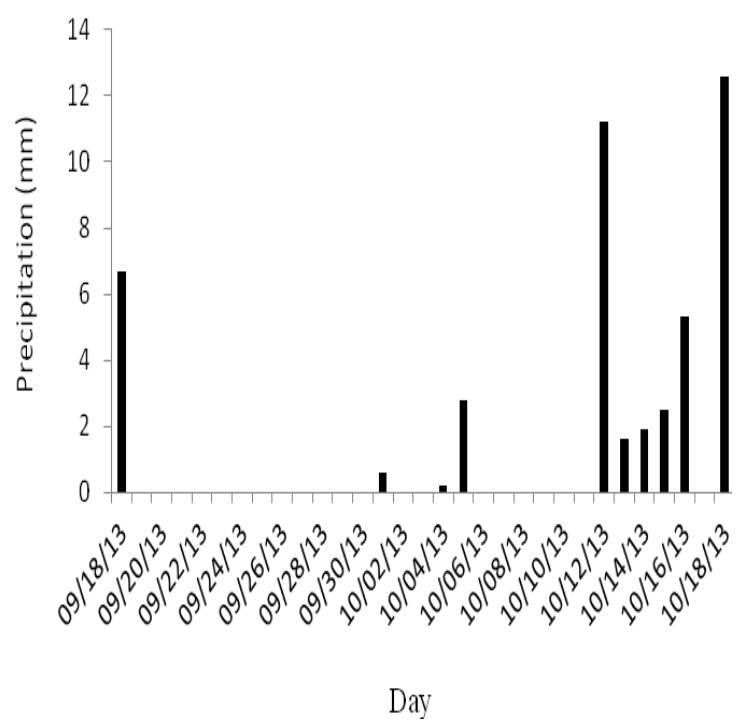

Figure 2. Antecedent precipitation to data collection (30 days).
Table 1. Mean percentage (\%) of volumetric soil moisture using TDR sensor at three different depths

\begin{tabular}{cccc}
\hline \multirow{2}{*}{ Point } & \multicolumn{3}{c}{ Depth } \\
\cline { 2 - 4 } & $0.00-0,12 \mathrm{~m}$ & $0.12-0.24 \mathrm{~m}$ & $0.24-0.36 \mathrm{~m}$ \\
\hline P1 & 34 & 27 & 17 \\
P2 & 40 & 25 & 15 \\
P3 & 27 & 21 & 15 \\
P4 & 40 & 35 & 23 \\
P5 & 40 & 21 & 15 \\
P6 & 37 & 24 & 16 \\
P7 & 39 & 31 & 16 \\
P8 & 34 & 23 & 16 \\
P9 & 37 & 31 & 15 \\
\hline $\begin{array}{c}\text { General } \\
\text { average }\end{array}$ & 36 & 26 & 16 \\
\hline
\end{tabular}

The spatial distribution of water content based on the average for each point and depths is shown in Figure 3. Therefore, values of soil moisture between 18 and $56 \%$ were observed. Koetz et al. 2010 did a work near the area addressed in this research that indicated that the maximum moisture near the saturation condition is $52 \%$ of moisture on a volumetric basis. However, considering the values of each repetition, it was observed a variation of approximately $10 \%$ between the measured values in the field and on the water retention 
curve of the soil described by this paper cited above. Several authors recommend the constant calibration of these sensors in the soil and specific crop lifting system to minimize variations caused by the error associated with the calibration of the sensor from the manufacturer, which may result in misleading analyzes of soil moisture (COSTA et al., 2013; LOPES et al., 2010). This equation, by the way, is not provided by the manufacturer.

It can also be seen in Figure 3, the variability in the three different layers analyzed. In the first layer (Fig. 3a) is observed that the prior precipitation (Figure 2) induced a contribution of this water layer thus promoting a high variability of the water content distribution in the soil. This variability decreases as the depth increases the soil. With a moderately variable distribution (Figure $3 b$ ) to a very low variability (Figure $3 \mathrm{c}$ ) on the layer of 0.24 to $0.36 \mathrm{~m}$. It is evident that the antecedent precipitation was not sufficient to reach the deepest layer due to the low water content in the soil observed. While in the outermost layer are observed values ranging from $35 \%$ to $50 \%$ in the deepest layer these values drop to around $15 \%$.

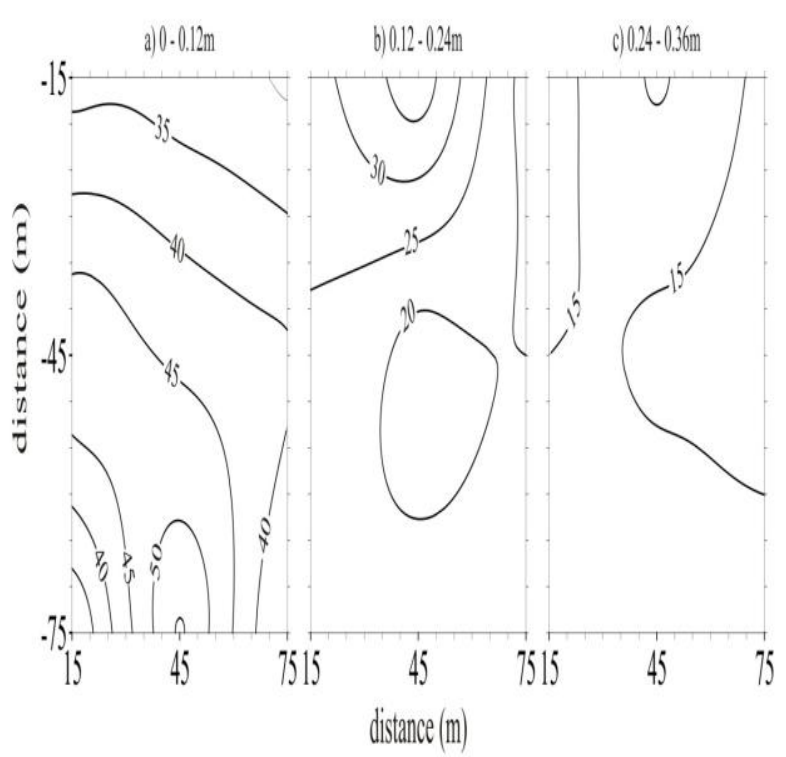

Figure 3. Spatial distribution of water content in soil as a percentage of the tillage system on Oxisol in three layers: (a) 0.00 to $0.12 \mathrm{~m}$, (b) from 0.12 to $0.24 \mathrm{~m}$; (c) from 0.12 to $0.24 \mathrm{~m}$.

It is identified in the analysis of variability in the layers of water content in soil also a gradual reduction of the variability of this parameter (Figure 4). In the first layer, the 36 samples analyzed values ranged from 20 to $55 \%$, in the second layer from 12 to $40 \%$ and in the third layer from 8 to $22 \%$ considering the extreme values. The average water content in soil layers (Table 1) indicate values of $36 \%$ in layer $0.00-0.12 \mathrm{~m}, 26 \%$ in layer $0.12-0.24 \mathrm{~m}$ and $16 \%$ in layer of 0.24 to $0.36 \mathrm{~m}$. 


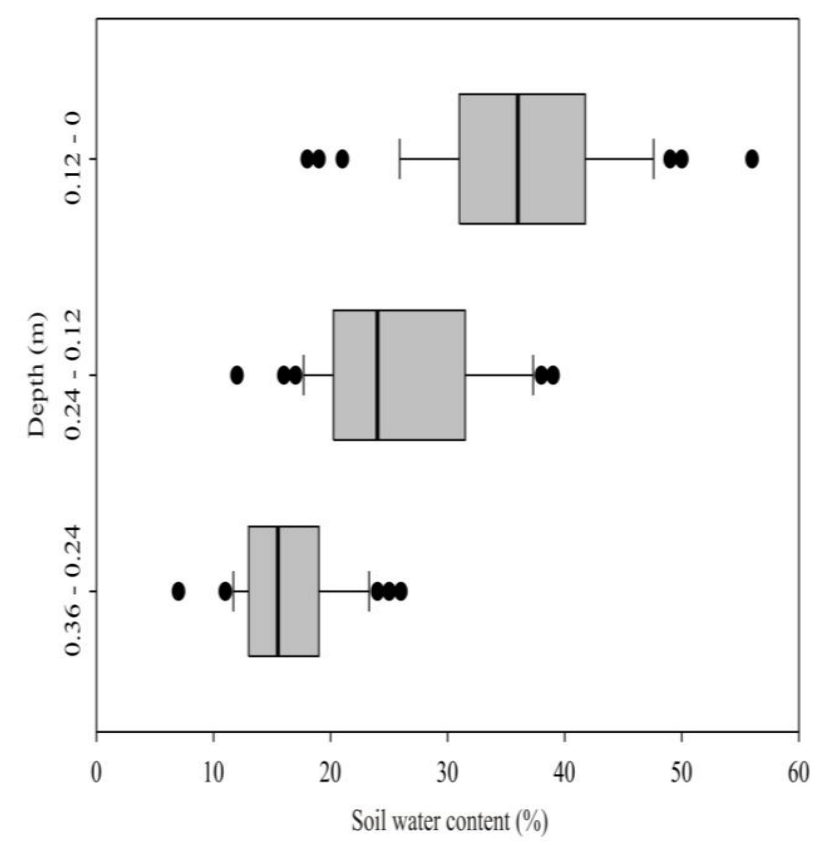

Figure 4. Box-plot variability of soil water content as a percentage of the tillage system on Oxisol in three layers: (a) 0.00 to $0.12 \mathrm{~m}$, (b) from 0.12 to $0.24 \mathrm{~m}$; (c) from 0.12 to $0.24 \mathrm{~m}$.

Applying the technique of non-parametric statistics, note the average relative difference for each geo-referenced point (Figure 5), which for depth from 0 to $0.12 \mathrm{~m}$, the points 6 and 9 proved to be the closest to the overall average, in other words, differences in average near zero, equal to 1.6. Considering the depth of 0.12 to 0.24 , point 1 had the lowest average relative difference. And in the layer of $0.24-0.36 \mathrm{~m}$, the points 1 and 8 stood out with an average relative difference with lower values. The points mentioned above are considered ideal for soil sampling in their depths specifically for the date the collection was made, but a temporal analysis to determine the point for continuous moisture monitoring with reduced effort and cost of sample is required.
It is still observed in Figure 5 that the relative difference proposed by Vachaud et al. (1985) under the conditions of this study shows a greater dispersion of points around zero in the layer of $0.12-0.24 \mathrm{~m}$. While the superficial and deeper layers the same number of points were observed near the zero point with only a relatively greater difference thus forming two distinct groups of behavior moisture. In the intermediate layer, there are three groups of behavior moisture. Two points (P1 and P2) as the best spots to represent the average of this parameter, three points (P3, P4, P5) with higher relative differences and four points (P6, P7, P8 and P9) with differences in averages. Therefore, the layer 0.12 to $0.24 \mathrm{~m}$ in these conditions presents three groups of behavior of water content in soil. This means that the high variability of this parameter in depth.

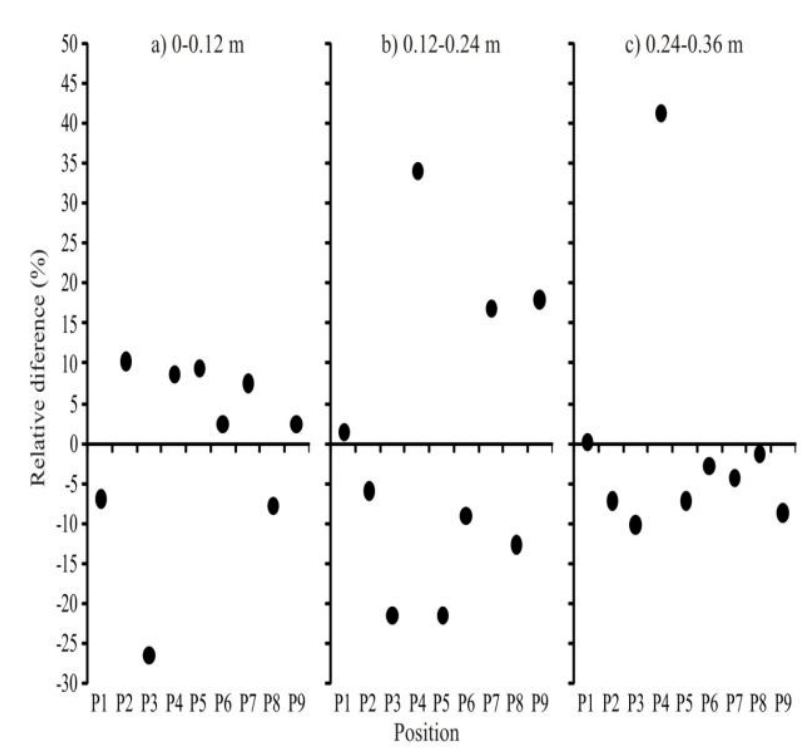

Figure 5. Average relative difference in the depths of (a) 0.00 to $0.12 \mathrm{~m}$, (b) from 0.12 to $0.24 \mathrm{~m} \mathrm{e}$ (c) from 0.12 to $0.24 \mathrm{~m}$. 


\section{CONCLUSIONS}

There was considerable variation between the values of volumetric soil moisture, with marked differences in the soil profile due to the small amount of rain occurred days before collection, in days that finalized the dry season.

Positions 1, 6, 8 and 9 stood out as ideal for monitoring soil moisture for the specific day on which points the collection of moisture for the experiment was performed and is therefore necessary to carry out continuous monitoring of moisture also along the time.

This preliminary analysis of the distribution of soil moisture, provide elements for refined calibration of this instrument enabling a larger sample moisture data measured directly in the field without the need to collect soil samples and subsequent laboratory analysis.

\section{ACKNOWLEDGMENTS}

Thanks go to CAPES, for the award of scholarship, to the Federal University of Goiás (UFG), for the technical and scientific support and for providing the experimental area, and to professors, students and staff. To the soil laboratory of UFG, Jataí Campus And also to the professor Dr. Raimundo Rodrigues Gomes Filho, from Federal University of Sergipe for his intellectual support on this work.

\section{REFERENCES}

ÁVILA, L. F.; MELLO, C. R. DE; SILVA, A. M. DA. Estabilidade temporal do conteúdo de água em três condições de uso do solo, em uma bacia hidrográfica da região da serra da Mantiqueira, MG. Revista Brasileira de Ciência do Solo, 34: 2001 - 2009, 2010.

BELL, K. R., BLANCHARD, B. J., SCHMUGGE, T. J., WITCZAK, M. W. Analysis of surface moisture variations within large field sites.Water Resources Research 16, 796-810, 1980.

BROCCA, L., MORBIDELLI, R., MELONE, F., MORAMARCO, T. Soil moisture spatial variability in experimental areas of central Italy. Journal of Hydrology 333, 356-373, 2007.

BROCCA, L.; MELONE, F.; MORAMARCO, T.; MORBIDELLI, R. Soil moisture temporal stability over experimental areas in Central Italy. Geoderma 148, 364-374, 2008.

COSTA, C. A.G; LOPES, J. W. B.; PINHEIRO, E. A. R. DE ARAÚJO, J. C.; GOMES FILHO, R. R. Spatial behaviour of soil moisture in the root zone of the Caatinga biome. Revista Ciência Agronômica. v. 44. p. 685-694, 2013.

EMBRAPA- Brazilian Agricultural Research Corporation. Brazilian system of soil 
classification. Brasilia: Embrapa/CNPS, 1999.

FITZJOHN, C., TERNAN, J.L., WILLIAMS, A.G. Soil moisture variability in a semi-arid gully catchment: implications for runoff and erosion control. Catena. 32, 55-70, 1998.

FRANCIS, C. F., THORNES, J. B., ROMERO, DIAZ, A., LOPEZ, A., BERMUDEZ, A., FISHER, G. C. Topographic control of soil moisture, vegetation cover and land degradation in a moisture stressed Mediterranean environment. Catena 13, 211225, 1986.

HUPET, F., VANCLOOSTER, M. Intraseasonal dynamics of soil moisture variability within a small agricultural maize cropped field. Journal of Hydrology 261, 86-101, 2002.

HUPET, F., VANCLOOSTER, M. Microvariability of hydrological processes at the maize row scale: implications for soil water content measurements and vapotranspiration estimates. Journal of Hydrology 303, 247-270, 2005.

KOETZ, M.; CHURATA-MASCA, M. G. C.; CARNEIRO L. C.; RAGAGNIN, V. A.; DE SENA JUNIOR, D. G.; RAIMUNDO RODRIGUES GOMES FILHO. Caracterização agronômica e Obrix em frutos de tomate industrial sob irrigação por gotejamento no sudoeste de goiás . Revista Brasileira de Agricultura Irrigada v. 4, n. 1, p.14 - 22, 2010.

LIN, H.S.; KOGELMANN, W.; WALKER, C.; BRUNS, M.A. Soil moisture patterns in a forested catchment: a hydropedological perspective. Geoderma 131, 345-368, 2006.

LOPES, J.W.; COSTA, C.A.G.; PINHEIRO, E.A.R.; TOLÊDO, C.E.; DE ARAÚJO, J.C.Calibração in loco de sensor de umidade de solo sob vegetação de Caatinga preservada. In: IX Congresso Latinoamericano y del Caribe de Ingenieria Agrícol - CLIA 2010 e XXXIX Congresso Brasileiro de Engenharia Agrícol CONBEA 2010, Vitória. Anais...p.1-10, 2010.

MORETI, D.; LIBARDI, P. L.; ROCHA, G. C.; LOVATTI, M. J.; AGUIAR, L. I. G. Avaliação espaço-temporal das armazenagens gravimétrica e volumétrica da água num Latossolo com citros. Revista Brasileira de Ciência do solo, v.31, p. 1281-1290, 2007.

MUNOZ-PARDO, J., RUELLE, P., VAUCLIN, M. Spatial variability of an agricultural field: geostatistical analysis of soil texture, soil moisture and yield component of two rainfed crops. Catena 17, 369-381, 1990.

SEYFRIED, M. Spatial variability constraints to modeling soil water at different scales. Geoderma 85, 231-254, 1998. 
SCHUME, H., JOST, G., KATZENSTEINER, K. Spatio-temporal analysis of the soil water content in a mixed Norway spruce (Picea abies (L.) Karst.)-European beech (Fagus sylvatica L.) stand. Geoderma 112, 273-287. 2003.
VACHAUD, G.; PASSERAT DE SILANS, A.; BALABANIS, P. \& VAUCLIN, M. Temporal stability of spatially measured soil water probability density function. Soil Sci. Soc. Am. J., 49:822-827, 1985. 